\title{
Collective symbolic capital and sustainability: Governing fishing communities in a knowledge economy
}

\author{
Alfredo Macías Vázquez ${ }^{\mathrm{a}, 1}$, Pablo Alonso González ${ }^{\mathrm{b}, *}$ \\ ${ }^{a}$ Department of Economy, University of León, Campus de Vegazana s/n, 24071 León, Spain \\ ${ }^{\mathrm{b}}$ Archaeology Division, University of Cambridge, Downing Street, CB2 3DZ Cambridge, United Kingdom
}

\section{A R T I C L E I N F O}

\section{Article history:}

Received 18 August 2014

Received in revised form

17 November 2014

Accepted 17 November 2014

Keywords:

Commons

Governance

Knowledge

Labels

Symbolic capital

Shellfish

\begin{abstract}
A B S T R A C T
The sustainable management of shared fishery resources remains a research concern despite the theoretical advances of recent decades. In the context of globalization, governance of fisheries resources cannot be conceived aside from a general restructuring of the value chain and without taking into account the evolution of the standard of living of fishing communities. This paper argues that in knowledge-based economies, value creation is based on proper management of the friction between material and immaterial vectors associated with the activity of fisheries. The case study of the shellfish community of Carril in northwestern Spain is presented and analyzed, setting out potential labeling alternatives to empower local producers.
\end{abstract}

(c) 2014 Elsevier Ltd. All rights reserved.

\section{Introduction}

Academic debates on fisheries management have intensified in recent decades as a result of the failure of the formulas implemented during the second half of the twentieth century to address the overexploitation of common resources [22,25,32]. Today, technological change, the increasing role of the expert systems based on natural sciences, and the globalization of markets generate highly complex and intensely changing scenarios that quickly render obsolete the different forms of governance used to avoid the 'dynamics of collapse' $[31,35,40]$. After the failure of traditional governance schemes based on an ontology that privileged the role of the fishers who competed individually in the exploitation of open-access common resources [9,46], alternative approaches highlight the role of ecosystems [28,47]. Thus, the Ecosystem-Based Fisheries Management perspective focuses on the relations between fishing practices and marine ecosystems $[21,39,52]$. In turn, Local Ecological Knowledge deems fundamental to shed light on situated and local knowledge to overcome the idealization of scientific knowledge [3,29,34,47]. As a result of globalization and rapid technological changes, the Globalized Harvesting Knowledge approach underlines the key role of exogenous actors in shaping local fisheries [32].

\footnotetext{
* Corresponding author. Tel.: 34646114287.

E-mail addresses: amacv@unileon.es (A. Macías Vázquez), pa332@cam.ac.uk (P. Alonso González).

${ }^{1}$ Tel.: + 34987291728.
}

In this context, it is useful to adopt an inherently political and phronetic approach to fisheries management, emphasizing the complex power and social relations involved in the choices, values, concerns and goals sustained by different social actors [14,22,24]. The phronetic perspective acknowledges the relevance of natural sciences in fisheries management, but considers the socio-political context of equal relevance in the attempt to reach more democratic models of fisheries management. To address this issue, the case study connects the problem of the overexploitation of fishing resources with the new challenges posed by the need of local communities to more successfully insert themselves into global value chains $[15,18]$. In this regard, recent works point to novel analytic frameworks that incorporate comparative studies of the strategies of value generation developed by rural communities in their search for sustainability (e.g., [36]). These works underscore the need to establish symbolic connections between consumers and producers [13].

In a knowledge economy, the differential value of local production stems from their immaterial values, which are the result of the historical evolution of common experiences, ideas and practices of production and live. This differential character of local products can become a form of collective symbolic capital that provides added value to the material processes of production. The concept of symbolic capital was developed by Bourdieu [4] to describe the immaterial and non-economic values connected to an individual or social group. Symbolic capital is historically and culturally contingent, and can be acquired, exchanged and converted into other types of capital. Harvey [12] extends the concept 
of symbolic capital to places rather than to social groups, accounting for the mechanisms through which certain marks of distinction generate collective symbolic capital attached to territories, cities or places.

From this standpoint, the creation of value is increasingly linked to the capacity of communities to manage their collective symbolic capital in ways that do not threaten the long-term sustainability of fishing resources. However, the right management of this process of value generation demands communities to develop new capabilities, since it requires the implementation of complex and dynamic strategies to manage the friction between collective material values (marine ecosystem, aquaculture plots or technical equipment) and collective immaterial values (local know-how, collective action or marketing strategies). If local communities fail to do so, the most common scenario in a neoliberal context is the capture of collective symbolic capital by exogenous actors, a situation that usually derives in the disempowerment of local communities and the gradual depletion of material resources.

These issues are explored through the case of a community of shellfish gatherers in Carril (Galicia, Spain). Here, the expropriation of the collective symbolic capital by local bourgeoisies and transnational corporations has led to the deterioration of the collective material resources. The rentier strategies implemented by different actors such as purifying companies, wholesaler traders and commercial distributors, allow them to capture increasing shares of the added value associated to the collective symbolic capital of Carril shellfish. In the attempt to offset the devaluation of their income and achieve higher yields, local aquaculturists intensify shellfish production and replace native species by foreign ones, thus threatening the long-term sustainability of the material collective resources and lowering the quality of the product.

To analyze this process, a research methodology was tailored to the particularities of the case study of Carril. The social science methodology employed combines quantitative and qualitative methods and the different analytic perspectives of an economist and an anthropologist. First, statistics on prices and productivity were elaborated and analyzed. Then, a total of ten structured interviews were carried out with key social actors in the shellfish economy of Carril including local aquaculturists, representatives of professional trade unions and the regional administration, entrepreneurs in the businesses of marketing, hatchery and purification, and biologists. Since 2012, a long-term follow up of the phenomenon in journals and official reports has been performed, analyzing the transformations in the legislative framework concerning fisheries in Carril and broadly in the region of Galicia.

\section{Knowledge economy, collective symbolic capital and labeling}

For Rullani [43], the value of knowledge and, extensively, of collective symbolic capital is derived from the virtuous assemblage of three drivers. First, there is a value derived from the capacities of consumers to interpret the meanings, symbols, and knowledge incorporated into material production. Second, values increase depending on the capacities of diffusion and propagation of these meanings in the social sphere. The third driver concerns the distribution of value among the different stakeholders who participate in production in one way or another. In a knowledge economy, it is equally important to understand the material processes of production and the processes whereby immaterial values or collective symbolic capital can be co-opted or expropriated by different social actors in the value chain. In this context, the governance of common material resources is closely related to the management of the collective symbolic capital that results from the reputation of local products, knowledge, and practices among end consumers.
According to the proponents of the cultural political economy $[16,45]$, ensuring the reproduction of the social life of local communities requires combining the interest of classic political economy on issues of value, exchange, distribution, and power [17], with the main concerns of the cultural turn, including the social construction of value, knowledge, identity, and culture [7].

The processes of cultural differentiation related with local practices, knowledge, and heritage allow for the accumulation of collective symbolic capital because they provide meaning to material production. In the search for novel vectors of valorization, post-industrial capitalism incorporates these differential ways of life to capture surplus value in manifold ways through its 'cultural circuits' [48]. From a territorial vision of rural development, Ray describes this process as the emergence of a "culture economy," which "can be understood as strategies to transform local knowledge into resources available for the local territory, i.e., the recognition (or construction) and valorization of local knowledge" ([42], p. 9). This implies that the management of any material product in a post-industrial economy should focus on the "friction between the free reproducibility of knowledge and the non-reproducibility of the material" ([38], p. 296). As Pasquinelli points out, there is a "profound asymmetry between the cultural domain and the material economy: value is accumulated on the immaterial level but the profits are made on the material one" ([37], pp. 150-151). To preserve and reappropriate collective symbolic capital requires understanding that "the modern commodity is simply double, since two main dimensions can be recognized: the dimension of profit (value produced by individual work) and the dimension of rent (value produced by collective desire)" ([37], p. 139). Thus, profit is made in the vector of material production, which is subject to technical and environmental constraints, but the rent that can be extracted from the product derives from exogenous, symbolic, and dynamic qualities, whose marginal costs tend to zero.

Therefore, the situation of aquaculturist communities would probably improve with the implementation of some kind of placebased enclosure over the material common resource in combination with a greater legal ability to protect the revenues provided by collective symbolic capital, such as geographic certification programs or protected denominations of origin [20,49]. In fact, the consolidation of these distinction marks requires the existence of an institutionpublic, private, or common-that can monitor and punish noncompliance, and sponsor increased expertise inputs, the codification of local practices, and the transformation of local knowledge into a form of 'property' [30]. However, critics of programs of certification and labeling argue that the implementation of these strategies have paradoxically strengthened neoliberal practices and social actors $[10,27,33]$. These authors also question the ability of these strategies to effectively protect and preserve the collective symbolic capital of local communities [10].

As Ray points out, the strategy of enclosing the material commons to increase the chances for appropriating immaterial rents is just "one mechanism potentially available to localities" ([42], p. 15). Nonetheless, it would be necessary to adopt appropriate strategies for modulating the friction between material and immaterial vectors that would not only protect, but also strengthen and render more dynamic the management of collective symbolic capital in a context of globalization and technological change. In the field of agri-food products, it is clear how the enclosure of material resources leads to different dynamics of rent appropriation depending on how the enclosure of the material is assembled with the collective symbolic capital available at each location. Thus, there are different ways of establishing symbolic connections with historic traditions and cultural heritage, the local varieties of a specific product, environmental conditions, social activities, fairs and feasts, etc. That is, it is not enough to enclose the common material resource to ensure control over the stable rents provided by the legal security provided by a labeling 
strategy. Besides this, it is necessary to establish dynamic management strategies of the collective symbolic capital, creating cultural representations able to connect with the consumption desires of wider customer segments.

However, the complexity of the issue makes defining an overall successful model for these strategies a futile task: their results always depend on the different articulations between local and global contexts, and the power relations of different social actors within the value chain. Taking into account immaterial values as part of the 'common resource' increases the complexity of the issue for local communities, which usually leads to a loss of their agency in favor of expert systems and exogenous actors in better positions for managing collective symbolic capital [23]. Consequently, new articulations are established between the community and value chains at different scales. As Guthman points out, the important issues to be analyzed become "the actual mechanisms that might capture and/or retain value," the processes whereby "value is captured" and "where value actually comes in the first place" ([10], p. 460). Largely due to the neoliberal ethos that glorifies the role of the individual 'finder-keeper' entrepreneur [5], the increasingly rentier character of capitalist elites often leads to the exogenous appropriation of the collective symbolic capital generated by local communities, which are usually more concerned with material production $[2,26,50]$. In turn, this situation entails a deterioration of the living standards and the overall decline of the capacity of the community to manage common resources, which can derive from the 'dynamics of collapse' and the impoverishment of local population. Reversing this tragic dynamic requires not only the establishment of natural conservation measures, but fundamentally the adoption of a proactive role in the management of fisheries $[15,18]$ and specifically regarding the collective management of symbolic capital.

\section{A no-win situation for artisanal aquaculture in Carril: the expropriation of common symbolic capital and the deterioration of material resources}

Despite the fact that clams from Carril enjoy a high reputation among Spanish consumers, their traditional forms of exploitation are largely unknown at the regional and national levels. The production of shellfish in Carril involves the exploitation of bivalve mollusks based on artisan practices of exploitation of sandbanks divided into plots allocated under temporal concessions to families, some of whom have been working them for more than two centuries. This productive structure has led to a form of local knowledge that differs from other shellfish-producing areas. The cultivation techniques are similar to agriculture, comprising various tasks involving shellfish populations, predators, and the surrounding physical environment. On one hand, the low reproductive rate and slow growth of some species make it necessary to introduce hatchery-raised specimens in order to increase the production of the most demanded species in the market. On the other hand, the works of fertilization and preparation of sand banks have to be performed regularly due to the gradual decalcification of soils and the action of ocean currents. Those tasks are labor intensive and can often include the cleaning of seaweed on sand banks, which can become daily at some times of the year to prevent shellfish from suffocating and dying. In addition, the artisanal harvesting of clams has to be performed with rakes because trawl fishing is forbidden. This requires a lot of dedication and employing many workers because recollection campaigns are limited in time. Some of these practices are also present in free shellfishing, where performance is more related to the surface allocated for the extraction of seafood. However, increasing production in small-scale aquaculture requires an intensification of performance per square meter, which renders essential the adequate preparation of the seafloor, the cleaning of plots, and the improvement of collection techniques.

The high reputation of Carril clams among Spanish producers has entailed a significant accumulation of symbolic capital in the last decades. However, different exogenous actors are trying to capture the symbolic value generated by artisanal aquaculturists, causing a gradual decrease in the ability of the community to generate and appropriate value. The growing economic pressure from these actors has forced aquaculturists to intensify production and to introduce new foreign species such as the Japanese clam (Ruditapes philippinarum) to maintain their income levels. These changes have resulted in the overexploitation of the environment, lower yields, the overall worsening of the marine ecosystem, the stunting of specimens, the appearance of new pathogens, the decline of the quality of the product, and increased production costs.

One of the main exogenous actors pressuring local aquaculturists is local purification companies. The process of purification is fundamental to the treatment of shellfish due to the high level of toxins in the marine ecosystem. However, purification companies are harshly criticized by local aquaculturists, who accuse them of unfair competition practices including the uncontrolled import of foreign shellfish at low prices sold as 'Carril clam'. Clearly, purification companies are profiting from the symbolic capital of Carril clams while favoring the decline of the material quality of the product. In turn, this situation entails an abuse of market power position that pushes down purchasing prices in local fish markets. Moreover, the shellfish imports bring new pathogens to the marine ecosystem that affect the production of local aquaculturists. Given the high levels of corporatism of the Spanish state form, represented here by the regional administration of the Xunta de Galicia, the purification companies have forged partnerships with regional political powers so that legislation has consolidated their market power to the detriment of local producers. For instance, aquaculturists are prohibited from legally buying clams at cheap prices in the auction and putting them in nurseries until prices rise: they must forcefully purify their production, thus losing the possibility of increasing profit margins by playing with price differentials. This legislation openly favors purification companies and other intermediaries in the chain value, who are the main buyers of fresh shellfish at the auction and often push prices down by acquiring shellish at low prices from external supply sources, either from other Galician markets, illegal furtive captures, or foreign imports.

From the standpoint of the local actors interviewed, the main problem facing local communities in Carril is the need to gain control over marketing strategies to reduce price pressures that push to the overexploitation of the resource. The present investigation suggests, however, that it is at least equally important to counter the expropriation of collective symbolic value by exogenous actors. In theory, the small production of Carril clams could only supply proximity markets. However, in the peak season during Christmas time, most fisheries in Spain sell 'Carril clams', something unfeasible without the imports of foreign shellfish. In a post-industrial economy, the most adequate strategy to protect small local productions would be the enclosure of the scarce common material resource by local communities, while the creation of value would rely on the collective management of the common immaterial values, connecting the resource with a specific group of consumers-often those with high purchasing power. In theory, it would be necessary to develop a Protected Designation of Origin to carry out a highly valorized commercialization of the scarce resource, while precluding imported and poached shellfish to be sold as 'Carril clam'. However, this solution is not supported and even precluded by the corporatist regional government, which holds that the problems of communities to add value in the seafood marketing chains derives from lack of entrepreneurship (that purification companies could provide) and lack of scientific management of the fishing resources (which expert 
knowledge could provide). Here, expert knowledge is embodied by the group of maritime biologists working for the regional government and the main academic and research centers linked to the fishing and shellfish sector. These experts play a key role in determining the policies followed by the regional government in the attempt to counter the supposedly disruptive effects that the action of maritime communities brings about. In parallel, the regional government supports purification companies and considers them the most enterprising and modernizing actors in the territory.

Overall, the transition to a post-industrial and knowledge economy in Carril is being performed under an increased role of expert knowledge in governance structures and modern corporations, marginalizing local knowledge in the process of transition. This situation overlooks the fact that purification companies are not value producing actors or entrepreneurs, but rather capturers of the value produced by the local community, in a typical situation of 'finder-keeper' behavior $[5,11]$. Through their dominant role in the processing and marketing of the product and the support of their fraudulent practices by the regional government, purification companies have successfully managed to capture the symbolic value generated by local aquaculturists over time, which allows them to pressure local aquaculturists to lower prices. One of the major purification companies even uses ‘Carril clam' as a trademark (see Fig. 1).

From this perspective, the control of the common immaterial values allows the purification companies to put pressure on local producers to push prices downwards. This pressure forces aquaculturists to intensify farming to maintain their income levels. While natural shellfish banks have a yield of half a kilo per square meter, Carril farming plots provide between 10 and $12 \mathrm{~kg} / \mathrm{m}^{2}$. These extractive levels are criticized by maritime biologists who argue that the maximum yield should be $4.5 \mathrm{~kg} / \mathrm{m}^{2}$ [6]. The high farming densities reduce the size and meat content of shellfish and can have disastrous effects on the spreading of disease: during the last cockle campaigns, the mortality rate has approached $100 \%$. In addition, the import of foreign cheap mollusks has brought new pathogens to the area. In turn, poached shellfish extracted from highly polluted areas of the estuary can lead to sanitary risks that cannot be avoided by the purification of the product. In fact, poaching is the main threat to the reputation of shellfish because public opinion is highly sensitive to food crises caused by toxicity problems.

The behavior of the regional corporate powers exacerbates the loss of collective symbolic capital by the local community and the parallel decline of the common material resource: the actual shellfish from Carril. Thus, despite knowing that the characteristics of the marine ecosystem of Carril's estuary are fundamental to the outstanding growth and meat quality of Carril shellfish, the institutional monitoring of poaching and foreign imports remains feeble, and so is the control of industrial and urban discharges to the sea. The aquaculturists interviewed assured us that they constantly denounced these

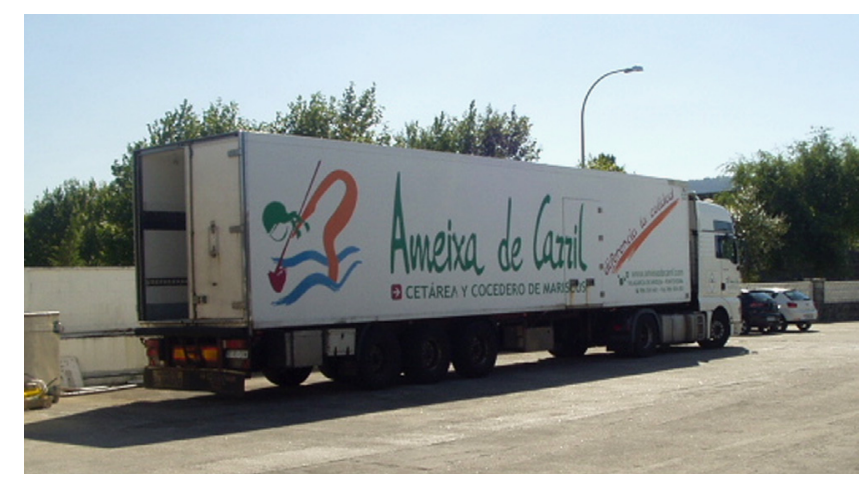

Fig. 1. Truck of the purification company Ameixa de Carril (Carril Clam). The company captures common immaterial values by using a brand name that coincides with the territorial ascription of the product.
Table 1

Average yearly prices of carpetshell clams in the auctions of Ría de Arousa, 2005$2014(€ / \mathrm{kg})$. Source: authors from data provided by the Consellería do Medio Rural e do Mar, Xunta de Galicia.

\begin{tabular}{lrrrrrrrrrrr}
\hline & $\mathbf{2 0 0 5}$ & $\mathbf{2 0 0 6}$ & $\mathbf{2 0 0 7}$ & $\mathbf{2 0 0 8}$ & $\mathbf{2 0 0 9}$ & $\mathbf{2 0 1 0}$ & $\mathbf{2 0 1 1}$ & $\mathbf{2 0 1 2}$ & $\mathbf{2 0 1 3}$ & $\mathbf{2 0 1 4}$ \\
\hline Carril & 9.9 & 10.0 & 11.8 & 10.1 & 8.7 & 10.1 & 10.2 & 7.3 & 9.1 & 9.7 \\
Cambados & 12.6 & 14.5 & 14.8 & 14.1 & 12.9 & 13.1 & 13.5 & 11.7 & 12.0 & 12.8 \\
$\begin{array}{l}\text { Arousa } \\
\quad \text { Island }\end{array}$ & 15.5 & 15.4 & 14.0 & 12.7 & 12.2 & 12.5 & 12.6 & 10.7 & 11.8 & 12.1 \\
\hline
\end{tabular}

a Data from 2014 are provisional and cover the period from January to June.

issues, as well as the little care for the maintenance of sea and river floors, which leads to the expansion of sludge over the artificial sand farming banks. Sludge increases mortality rates and darkens mollusks' shells, effects that have a negative impact on consumers' perceptions of the product. On the other hand, the European Parliament's current governing party members-Partido Popular-want to avoid indicating the origin of the product in the labeling of seafood in the European market [1]. This practice goes against the logic of protecting localized and scarce productions and overtly favors transnational fishing and canning industries who delocalize their production to low income countries, but who are eager to control the common immaterial values provided by the famous shellfish products from Galician estuaries.

These factors have led to a gradual decrease in the ability of local producers to generate and appropriate value. This becomes apparent when comparing the price differentials in native clams (pullet carpet shell, Venerupis pullastra) between the auction of Carril and other auctions appertaining to the same marine ecosystem (see Table 1). This negative price differential at Carril's auction is striking because the end consumer pays a higher price for a product called 'Carril clam' (see Fig. 2). Those benefitting from this increase in profit margins are the actors able to capture the collective symbolic capital such as neighboring auctions, purification companies, and wholesale importers. However, this logic can end up harming these actors as well, because it opens the door for other exogenous 'finders-keepers' to profit from the situation thanks to their higher control of the price differentials in global markets and their better management of symbolic capital.

This is evinced in the ongoing crisis of most purification companies. First, this is due to the prolonged economic crisis in Spain, which lowers demand for shellfish and consequently its prices. Second, wholesale traders have better managed to appropriate the symbolic value of Carril clams, replacing purification companies. In fact, distribution centers in large cities such as Madrid or Barcelona market many mollusks from different origins and trade them as 'Carril clam'. Recent changes in shellfish markets have entailed a qualitative leap in the expropriation of the collective symbolic capital of 'Carril clam' that has negatively affected local purification companies. As they have argued in the interviews performed, most shellfish imports from Portugal and Italy, previously purified in Carril, are now purified in origin and sent directly to wholesale traders in distribution centers-who, of course, sell them as 'Carril clam'. Tellingly, most actors involved in shellfish production tend to omit one key actor devoid of representation in local shellfish governance: consumers. Those are clearly affected and deceived by misleading labeling practices and artificially inflated prices, which poses the question of the adequate scale and framework for fisheries governance.

\section{Conclusions}

Following the authors who advocate a phronetic approach to the social sciences and in particular to fisheries management $[8,22]$, the case study of Carril suggests that the problems of sustainable governance of material, and especially immaterial 


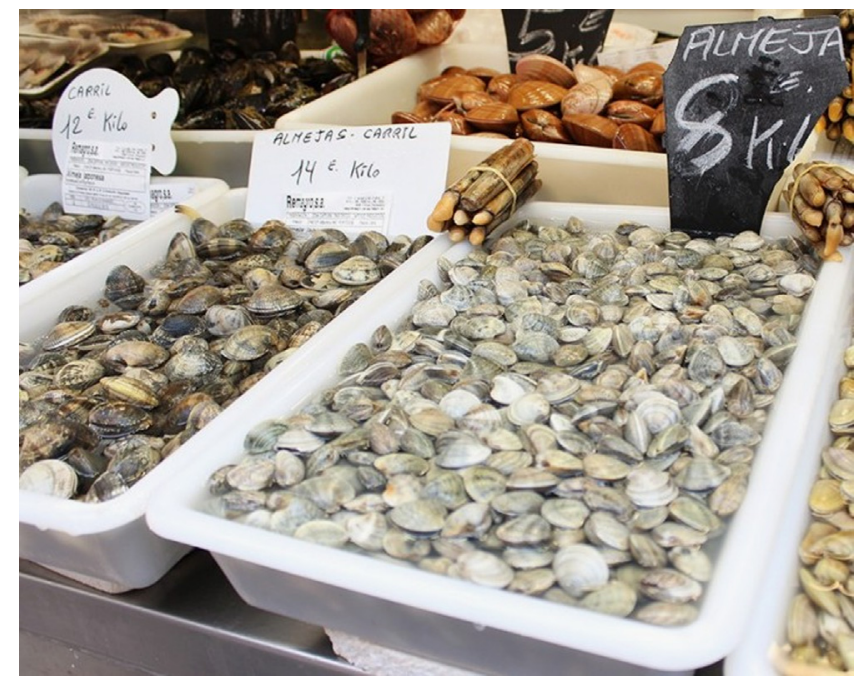

Fig. 2. A fishery in southern Spain, 1000 kilometers away from Carril. Common clams are sold at $8 € / \mathrm{kg}$ while the so-called 'Carril Clam' ranges between 12 and $14 € / \mathrm{kg}$.

common resources, demands a greater involvement of the social sciences. The achievement of sustainability cannot be left exclusively in the hands of natural science expert systems based on technical and scientific criteria. This is so because the management of common resources is ultimately a political issue, as it involves a complex interaction between social values, power relations, ideologies, and ethics. Therefore, social scientists should play a key role in understanding these complex interactions that are based on a kind of rationality that differs from the technoscientific criteria usually applied in fisheries management [22]. In this regard, Khan and Neis [18] argue the need to shift from a 'recovery imperative' to a 'rebuilding imperative' where the primary objective is not only the recovery of fishing stocks. Rather, it involves rebuilding the overall value chain, from the marine ecosystem to the final consumer, incorporating the different dimensions of governance such as environmental sustainability, food security and the welfare of local fishing communities.

In Carril, local aquaculturists are gradually losing agency because of the serious deficiencies in the management of their symbolic capital. The rent-seeking strategies implemented by purification companies and wholesalers allow them to capture a growing share of the added value associated with the significant collective symbolic capital historically accumulated in Carril. In turn, aquaculturists drain their common material resource by intensifying their crops and replacing native species to achieve higher yields, in the attempt to compensate for their decreasing incomes as a consequence of their loss of agency in the value chain. Among other factors, the study in Carril suggests that the disempowerment of the local community results from a misunderstanding about the creation and appropriation of value in a knowledge-based economy. However, this problem is not exclusive to Carril. As discussed by Olson et al. [36], it would be necessary to incorporate the cultural dimension to studies of fisheries in order to understand the perception different actors have of the value chain.

The products from Carril present competitive advantages in relation with other fishery goods, because a large majority of consumers can interpret the differential character of Carril clams and are willing to pay more for it. Usually, this is the most difficult driver to manage successfully in agro-food Spanish products due to a lack of a consumer culture in this regard. However, the present study suggests that the collective management of other fundamental sources of value in a knowledge economy is largely deficient in the village. On one side, the multiplication of common immaterial values associated with Carril's shellfish is high, but the management of those values tends to blur the distinctive identity of the product. This is the result of massive sales of imported and poached shellfish as 'Carril clam'. On the other side, profits are not shared equitably due to the inadequate community management of common immaterial values, which eases the establishment of rents by exogenous actors who gain an increasing power in the value chains. This situation is reflected in the growing shellfish price differential between the low prices at Carril's auction and the high prices paid by end consumers. Those are not only paying more for the product, but are also being deceived because most shellfish labeled as 'Carril clam' is not actually from Carril. This situation evinces the need for more democratic governance forms of fisheries where consumers and the overall public are represented. In this sense, the present investigation concurs with Jentoft when he argues that "we need more politics in fisheries management, not less" (2006, p. 673).

To advance in the solution of these problems, it is necessary to rethink community governance strategies that allow the sustainable management of fishery resources. Furthermore, governance strategies must be directed at strengthening the position of local producers in the value chain, improving their capacities in the management of collective symbolic capital. The investigation in Carril suggests that these changes should be developed in two phases. First, it would be necessary to enclose the collective material resource through a Protected Designation of Origin to carry out a highly valorized commercialization of the scarce resource $[41,51]$. This would also preclude imported and poached shellfish to be sold as 'Carril clam'. However, labeling strategies are not enough. In a second phase, it would be necessary to establish a dynamic management of the collective symbolic capital. This involves the development of strategies for the modulation of the material and immaterial vectors of value creation, connecting cultural representations of products from Carril with consumer desires. The establishment of these types of connections between consumers and differentiated products become possible under knowledge economies and can be a source of added value, but they require the development of more complex skills and capabilities than those associated with 'traditional' material production. On one hand, the expansion of markets demands a more sophisticated reflection on the more diverse and increasingly changing desires of consumers. On the other hand, the need to endow meaning and values to material production involves the incorporation of alternative forms of expert knowledge derived from the social sciences and from the fields of esthetic and cultural creation.

These two phases are tightly interrelated. Indeed, labeling strategies such as Protected Designations of Origin cannot be understood as legal devices to protect the rents associated to the collective symbolic capital of a specific product. Rather, they should play a dynamic role in the management of different socio-economic activities, from the diffusion of innovation, to marketing and the creation of new symbolic representations that improve the reputation of local products in the market [44]. In turn, a greater ability to generate more inclusive and dynamic strategies of collective action in the management of local collective symbolic capital can improve labeling strategies.

As Kirby et al. [19] point out in their analysis of eco-labeling schemes in Pacific tuna fisheries, the wide diversity of social interests at play requires efficient governance strategies to ensure the sustainable exploitation of common resources. Probably, the adoption of similar mechanisms in Carril would allow local aquaculturists to overcome the current dynamics of private capture of the collective symbolic capital based on a 'finders-keepers' behavior among local actors linked to commercialization networks, wholesalers, and transnational companies. An improved community management of the collective symbolic capital may prevent the opportunistic behavior of these actors, or at least reduce it to a minimum. Advancing in this direction requires that local 
aquaculturists establish more dynamic and meaningful connections with consumers, and the development of governance schemes that ensure a fair distribution of the benefits provided by the added value of collective symbolic capital among all local producers.

\section{References}

[1] Abuín E. La Eurocámara aprueba eliminar en las latas el origen del contenido. La Voz de Galicia; 13 September, 2012.

[2] Alonso Gonzalez P. From a given to a construct: heritage as a commons. Cult Stud 2014:28(3):359-90.

[3] Berkes F. Sacred ecology: traditional ecological knowledge and resource management. Philadelphia: Taylor \& Francis; 1999.

[4] Bourdieu P. Distinction: a social critique of the judgement of taste. Cambridge, MA: Harvard University Press; 1984.

[5] Burczak T. A critique of Kirzner's finders-keepers defense of profit. Rev Austrian Econ 2002;15(1):75-90.

[6] Cerviño Otero A. (Unpublished PhD dissertation). Ciclo reproductivo, cultivo en criadero y en el medio natural de la almeja babosa Venerupis pullastra (Montagu, 1803). Santiago de Compostela: Universidad de Santiago de Compostela; 2012.

[7] Cloke P. Country backwater to virtual village? Rural studies and the cultural turn J Rural Stud 1997;13(4):367-75.

[8] Flyvbjerg B. Making social science matter: why social inquiry fails and how it can succeed again. Cambridge: Cambridge University Press; 2001.

[9] Gordon HS. The economic theory of a common-property resource: the fishery. J Polit Econ 1954;62:124-42.

[10] Guthman J. The Polanyian way? Voluntary food labels as neoliberal governance Antipode 2007;39(3):456-78.

[11] Hanlon G. The entrepreneurial function and the capture of value: using Kirzner to understand contemporary capitalism. Ephemera: Theory Polit Organ 2014;14(2):177-95.

[12] Harvey D. Rebel cities: from the right to the city to the urban revolution. London; New York: Verso Books; 2012.

[13] Iles A. Making seafood sustainable: merging consumption and citizenship in the United States. Sci Public Policy 2004;31(2):127-38.

[14] Jentoft S. Beyond fisheries management: the Phronetic dimension. Mar Policy 2006;30(6):671-80.

[15] Jentoft S, Chuenpagdee R. Fisheries and coastal governance as a wicked problem. Mar Policy 2009;33(4):553-60.

[16] Jessop B, Oosterlynck S. Cultural political economy: on making the cultural turn without falling into soft economic sociology. Geoforum 2008;39 (3):1155-69.

[17] Jones M. Recovering a sense of political economy. Polit Geogr 2008;27 (4):377-99.

[18] Khan AS, Neis B. The rebuilding imperative in fisheries: clumsy solutions for a wicked problem? Prog Oceanogr 2010;87(1):347-56.

[19] Kirby DS, Visser C, Hanich Q. Assessment of eco-labelling schemes for Pacific tuna fisheries. Mar Policy 2014;43:132-42.

[20] Lagrange L. Signes officiels de qualité et développement agricole. Actes de colloque SFER. Paris: Technique \& Documentation; 1999.

[21] Langton RW, Auster PJ, Schneider DC. A spatial and temporal perspective on research and management of groundfish in the northwest Atlantic. Rev Fish Sci 1995;3(3):201-29.

[22] Linke S, Jentoft S. Exploring the phronetic dimension of stakeholders' knowledge in EU fisheries governance. Mar Policy 2014;47:153-61.

[23] Macías Vázquez A, Saavedra Gallo G. Tradición e innovación en las comunidades de pesca artesanal del sur de Chile: hacia un enfoque reflexivo del desarrollo endógeno. AIBR Rev Antropol Iberoam 2012;7(1):33-63.

[24] Mahon R, McConney P, Roy RN. Governing fisheries as complex adaptive systems. Mar Policy 2008;32(1):104-12.

[25] Mansfield B. Neoliberalism in the oceans: "rationalization," property rights, and the commons question. Geoforum 2004:35(3):313-26.
[26] Marazzi C. Capital and language: from the new economy to the war economy Los Angeles; Cambridge: Semiotext(e); 2008.

[27] Marsden T, Smith E. Ecological entrepreneurship: sustainable development in local communities through quality food production and local branding. Geoforum 2005;36(4):440-51.

[28] McCay BJ. Post-modernism and the Management of Natural and Common Resources. Common Prop Resour Dig 2000;54:1-6.

[29] McCay BJ, Jentoft S. From the bottom up: participatory issues in fisheries management. Soc Nat Resour 1996:9(3):237-50.

[30] Moran W. Rural space as intellectual property. Polit Geogr 1993;12(3):263-77.

[31] Mullon C, Fréon P, Cury P. The dynamics of collapse in world fisheries. Fish Fish 2005;6(2):111-20.

[32] Murray G, Neis B, Johnsen JP. Lessons learned from reconstructing interactions between local ecological knowledge, fisheries science, and fisheries management in the commercial fisheries of Newfoundland and Labrador, Canada. Hum Ecol 2006;34(4):549-71.

[33] Mutersbaugh T. Fighting standards with standards: harmonization, rents, and social accountability in certified agrofood networks. Environ Plan A 2005;37 (11):2033.

[34] Neis B, Felt L. Finding our sea legs: linking fishery people and their knowledge with science and management. St. John's, Newfoundland: ISER; 2000.

[35] Neis B, Kean R. Why fish stocks collapse: an interdisciplinary approach to the problem of "fishing up". In: Byron R, editor. Retrenchment and regeneration in rural Newfoundland. Toronto: University of Toronto Press; 2003. p. 65-102.

[36] Olson J, Clay PM, Pinto da Silva P. Putting the seafood in sustainable food systems. Mar Policy 2014;43:104-11.

[37] Pasquinelli M. Animal spirits: a bestiary of the commons. Rotterdam; New York: NAi; 2008

[38] Pasquinelli M. The ideology of free culture and the grammar of sabotage. In Araya D, Peters M, editors. Education in the creative economy: knowledge and learning in the age of innovation. New York: Peter Lang; 2010. p. 285-304.

[39] Pauly D. Putting fisheries management back in places. Rev Fish Biol Fish 1997;7(1):125-7.

[40] Perry R, Ommer R, Allison A, Badjeck M, Barange M, Hamilton L, et al. Interactions between changes in marine ecosystems and human communities. In: Barange M, editor. Marine ecosystems and global change. Oxford; New York: Oxford University Press; 2010. p. 221-51.

[41] Potts T, Haward M. International trade, eco-labelling, and sustainable fisheries-recent issues, concepts and practices. Environ, Dev Sustain 2007;9 (1):91-106.

[42] Ray C. Culture, intellectual property and territorial rural development. Socio Rural 1998;38(1):3-20.

[43] Rullani E. Economia della conoscenza: creatività e valore nel capitalismo delle reti. Roma: Carocci; 2004

[44] Sanz Cañada J, Macías Vázquez A. Quality certification, institutions and innovation in local agro-food systems: protected designations of origin of olive oil in Spain. J Rural Stud 2005;21(4):475-86.

[45] Sayer A. For a critical cultural political economy. Antipode 2001;33 (4):687-708.

[46] Scott A. The fishery: the objectives of sole ownership. J Polit Econ 1955;63:116-24

[47] St Martin K, McCay BJ, Murray GD, Johnson TR. Communities, knowledge and fisheries of the future. Int J Glob Environ Issues 2007;7(2):221-39.

[48] Thrift NJ. Knowing capitalism. London: SAGE; 2005.

[49] Valceschini, E. Les signaux de qualité crédibles sur les marchés agroalimentaires: certifications officielles et marques. Paper presented at the Signes officiels de qualité et développement agricole. Actes de colloque SFER, Paris 1999.

[50] Vercellone C. The new articulation of wages, rent and profit in cognitive capitalism. Conference paper presented at The Art of Rent. London: Queen Mary University; 2008.

[51] Wessells C, Cochrane K, Deere C, Wallis P, Willmann R. Product certification and eco-labeling for fisheries sustainability: FAO Fisheries technical paper no. 422; 2001

52 Wilson J, Low B, Costanza R, Ostrom E. Scale misperceptions and the spatial dynamics of a social-ecological system. Ecol Econ 1999;31(2):243-57. 